\title{
Scientific uncertainty in public discourse: How scientists, media and audiences
} present und process scientific evidence

\author{
Maier, Michaela ; Post, Senja
}

DOI: https://doi.org/10.1515/commun-2016-0014

Posted at the Zurich Open Repository and Archive, University of Zurich ZORA URL: https://doi.org/10.5167/uzh-125875

Journal Article

Published Version

Originally published at:

Maier, Michaela; Post, Senja (2016). Scientific uncertainty in public discourse: How scientists, media and audiences present und process scientific evidence. Communications : European Journal of Communication Research, 41(3):229-230.

DOI: https://doi.org/10.1515/commun-2016-0014 


\section{Editorial}

Michaela Maier and Senja Post

\section{Scientific uncertainty in public discourse: How scientists, media and audiences present und process scientific evidence}

DOI 10.1515/commun-2016-0014

Scientific findings are inherently uncertain. Oftentimes, for instance, scientific investigations yield ambiguous states of affairs rather than clear facts. Many a time, scientists reach contradictory conclusions and usually, a research field includes many open questions. According to modern philosophies of science, scientific evidence is principally tentative as it can never be ruled out that it will be proven wrong in the future (Popper, 1959). Yet, in order for science to proceed, it has to accept facts as given when scientific consensus on particular research issues is reached (Kuhn, 1967; Popper, 1959).

Scientific issues have become increasingly important in news coverage as more and more environmental problems and modern technologies are discussed in public. This raises the question as to how journalists, and other communicators, account for scientific evidence and how the audience processes this information. For example, past research has found that journalists tend to neglect scientific uncertainty in their depictions of scientific evidence (see Stocking and Holstein, 1993). However, more recent studies have pointed out that in controversial public debates, scientific uncertainty can be used strategically for political purposes, playing it down to stress the necessity of certain policy programs or playing it up to question them (Oreskes and Conway, 2010).

In this Special Issue of Communications we seek to answer how scientists, the media, and audiences present und process scientific evidence in public discourse. The introduction by Sharon Dunwoody will recap the development of this research as a substantial field of communication science. As Dunwoody points out, despite increasing interest within the scientific community, many questions regarding media representations of scientific evidence and audience

Michaela Maier, University of Koblenz-Landau, E-mail: mmaier@uni-landau.de Senja Post, University of Zurich, E-mail: s.post@ipmz.uzh.ch 
reactions have not been answered yet. However, these questions become increasingly pressing as citizens' dependency on scientific findings and technical innovations in everyday life steadily increases, and understanding of scientific processes becomes a prerequisite for individual science and technology-related attitude-formation and decision-making.

These and other research deficits have also been recognized by the German Research Foundation, which launched the Special Priority Program 1409 Science and the Public in 2009. This program has supported significant research efforts on the relationship between science and laypersons in psychology, communication research, linguistics, sociology and educational research over the last six years. This Special Issue is only one in a whole series of publications (see www.scienceandthepublic.de) summarizing the findings of this major research endeavor and linking it to current research in the international community. The present special issue presents a collection of works in communication research, dealing, among others, with the roles of scientists, the media, the lay public and online users in the public communication of scientific evidence. Readers also interested in perspectives of social, educational and cognitive psychology might be interested in the Special Issues of Educational Psychologist (2014, Volume 49) titled Understanding the public understanding of science: Psychological approaches (R. Bromme and S.R. Goldman, eds.) as well as Certainty and scepticism: Psychological approaches on understanding and communicating science (R. Bromme and D. Kienhues, eds.), forthcoming in Psychologische Rundschau [in German].

\section{References}

Bromme, R., \& Goldman, S. R. (Eds.). 2014. Understanding the public understanding of science: Psychological approaches. Special Issue of Educational Psychologist. 49(2).

Bromme, R., \& Kienhues, D. Eds. Forthcoming. Certainty and scepticism: Psychological approaches on understanding and communicating science. Psychologische Rundschau.

Kuhn, T. S. 1967. The structure of scientific revolutions ( $3^{\text {rd }}$ ed). Chicago, IL: University of Chicago Press.

Oreskes, N., \& Conway, E. M. 2010. Merchants of doubt: How a handful of scientists obscured the truth on issues from tobacco smoke to global warming. New York, NY: Bloombury Press.

Popper, K. 1959. The logic of scientific discovery. London: Hutchinson.

Stocking, S. H., \& Holstein, L. H. 1993. Constructing and Reconstructing Scientific Ignorance. Science Communication. 15(2). 186-210. 